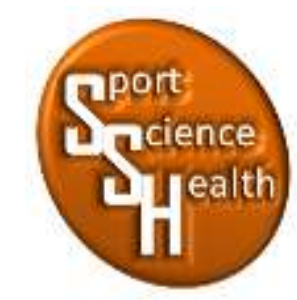

ISSN 2715-3886

\title{
Survei Tingkat Persepsi Siswa Terhadap Konsep Pendidikan Jasmani Di Sekolah Menengah Atas
}

\author{
Mukhammad Fitron Universitas Negeri Malang \\ Mu'arifin Universitas Negeri Malang \\ Mukhammadfitron@gmail.com \\ 081554452393
}

\begin{abstract}
Abstrak
Tujuan penelitian adalah untuk mengetahui tingkat persepsi siswa-siswi terhadap konsep pendidikan jasmani pada SMA Negeri Kabupaten Pasuruan. Populasi dari peneltian ini berjumlah 371 siswa se Kecamatan Kota Pasuruan dan peneltian ini mengunkan sampel berjumlah 360 . Instrumen pada penelitian ini menggunakan kuisoner inventori. Teknik analisis data pada peneltian ini mengunakan teknik analisis deskriptif kuantitatif. Analisis data kuantitif diperoleh dari hasil siswa mengisi kuisoner dan di analisis menggunakan rumus presentase. Hasil pengisian kuisoner tingkat persepsi siswa terhadap konsep pendidikan jasmani di SMA Negeri Kabupaten Pasuruan diperoleh $85,76 \%$. Perbedaan tingkat persepsi siswa laki-laki dan perempuan terhadap konsep pendidikan jasmani diperoleh nilai signifikan 0,003 dengan taraf signifikansi $>0,05$ artinya hipotesis diterima. Selanjutnya perbedaan tingkat persepsi siswa kelas $\mathrm{X}$ dan kelas $\mathrm{XI}$ terhadap konsep pendidikan diperoleh nilai signifikan 0,003 dengan taraf signifikan $>0,05$ artinya hipotesis diterima. Dengan demikian dapat disimpulkan bahwa tingkat persepsi siswa terhadap konsep pendidikan jasmani di SMA Negeri Kabupaten Pasuruan hasilnya sangat baik, tingkat persepsi siswa laki-laki dan perempuan terhadap konsep pendidikan jasmani mengalami perbedaan, dan tingkat persepsi siswa kelas $\mathrm{X}$ dan kelas $\mathrm{XI}$ terhadap konsep pendidikan jasmani mengalami perbedaan.
\end{abstract}

\section{Kata kunci}

persepsi, konsep pendidikan jasmani.

\section{PENDAHULUAN}

Pendidikan adalah suatu kebutuhan yang sangat penting karena pendidikan adalah salah satu sektor untuk kemajuan negara. Mengetahui kegagalan Indonesia untuk mempertahankan kedaulatan dimasa lalu karena pendidikan saat itu masih lemah. Pendidikan merupakan lembaga yang diharapakan mampu membuat terobosan-terobosan untuk membawa negara ini untuk tidak ketinggalan dari negara-negara lain. Dalam dunia pendidikan, olahraga dimasukan disalah satu pembelajaraan jasmani yang harus dilakukan oleh setiap siswa satu pertemuan dalam satu minggu. Pendidikan jasmani dilakukan dari jenjang yang paling terendah sampai jenjang yang lebih tinggi SD, SMP, SMA. Pendidikan jasmani yang di ajarkan di sekolah memiliki peranan penting memberikan kesempatan bagi siswa untuk belajar melalui aktivitas-aktivitas jasmani. 
Pendidikan jasmani adalah bagian integral dari seluruh pendidikan dan memiliki tujuan aspek kebugaraan jasmani, keterampilan gerak keterampilan berfikir kritis, keterampilan sosial, penalaraan, stabilitas, emosional tindakan moral, aspek pola hidup sehat yang di rencanakan secara sistematik dalam rangka mencapai tujuan pendidikan nasional dan suatu usaha untuk membuat bangsa indonesia sehat dan kuat, diberikian kepada segala jenis sekolah. Pendidikan jasmani pada dasarnya merupakan bagian integral dari sistem pendidikan secara keseluruhan, bertujuan untuk mengembangkan aspek kasehatan, kebugaran jasmani, keterampilan berfikir kritis, stabilitas emosional, keterampilan sosial, penalaran dan tindakan moral melalui aktivitas jasmani dan olahraga Pendidikan jasmani adalah suatu kegiatan aktivitas gerak dengan proses interaksi antara pendidik dan siswa memanfaatkan perkembangan pengetahuan yang ada untuk meningkatan kebugraan jasmani (Manalu, Dwiyogo, \& Heynoek, 2020). Tujuan pendidikan jasmani adalah untuk meningkatkan kebugaran jasmani dan menjaga kesehatan peserta didik melalui aktivitas gerak.

Persepsi adalah sebuah tanggapan atau penerimaan langsung melalui panca inderanya untuk mengetahui segala hal yang dilihat disekitarnya. Persepsi dapat diartikan sebagai sebuah tanggapan atau penerimaan langsung dari sesuatu sebuah proses dalam diri seseorang untuk dapat mengetahui beberapa hal melalui panca inderanya. Persepsi adalah sebuah tanggapan atau penerimaan langsung melalui panca inderanya untuk mengetahui segala hal yang dilihat disekitarnya (Hansen, Sato, \& Ruedy, 2012). Oleh karena itu persepsi siswa terhadap pendidikan jasmani dibutuhkan untuk memahami konsep dan tujuan pendidikan jasmani dengan benar. Dengan adanya suatu persepsi pendidikan jasmani yang benar, siswa akan mencapai tujuan yang akan dicapai. Siswa diharapkan bisa mengetahui persepsi pendidikan jasmani. Dengan mengetahui persepsi pendidikan jasmani siswa akan termotivasi mengikuti pembelajaraan pendidikan jasmani. Persepsi yang baik terhadap pendidikan jasmani diharapkan untuk meningkatkan aktivitas pembelajaraan siswa disekolah. Adanya proses pembelajaraan yang meningkat akan merubah cara balajar siswa. Dengan mengetahui pendidikan jasmani dengan baik siswa lebih mudah mengikuti proses pembelajaran pendidikan jasmani dengan baik dan benar.

\section{METODE}

Rancangan penelitian ini menggunakan deskriftif kuantitatif dengan metode survei. Prosedur dari penelitian ini yaitu: (1) menemukan masalah, (2) menyusun kuisoner, (3) justifikasi para ahli, (4) melakukan penelitian, (5) melakukan validitas instrumen, dan (6) melakukan realibilitas instrumen. Penelitian ini mengunakan sampel yang berjumlah 360 siswa se Kabupaten Pasuruan. Instrumen pada penelitian ini menggunakan kuisoner inventori. Teknik analis data pada peneltian ini mengunakan teknik analisis deskriptif kuantitatif. Anlisis data kuantitatif diperoleh dari hasil siswa mengisi kuisoner dan di analisis menggunakan rumus presentase dan mengunakan uji prasyarat (uji normalitas) untuk menentukan rumus uji beda, yang mengunakan uji $U$ MannWhitney (Bird \& Bird, 2019).

Pada pengambilan data, Peneliti menyebarkan angket ke siswa kelas $\mathrm{X}$ dan XI pada enam SMA Negeri di Kabupaten Pasuruan. Kuesioner penelitian ini menggunakan pertanyaan yang jawabannya benar atau salah dan waktu mengerjakan kuesioner penelitian ini adalah 30 menit. Runtutan dalam pengambilan data penelitian ini sebagai berikut: (a) Menemukan masalah. (b) Menyusun proposal dengan pembimbing. (c) Seminar proposal (d) Menyusun kuesioner. (e) Menjustifikasikan instrumen ke para ahli. (f) Membuat surat izin penelitian ke Fakultas IImu Keolahragan Universitas Negeri Malang sebagai pengantar untuk meminta izin penelitian ke kantor Bakesbangpol Kabupaten Pasuruan, Dinas Pendidikan Kabupaten Pasuruan, dan Kepala sekolah SMAN 1 Grati, SMAN 1 Kejayan, SMAN 1 Bangil, SMAN 1 Gondang Wetan, SMAN 1 Purwosari, dan SMAN 1 Pandaan. (g) Mengurus surat izin penelitian ke Bakesbangpol Kabupaten Pasuruan yang dirujukkan ke Dinas Pendidikan Kabupaten Pasuruan yang selanjutnya dijadikan pengantar untuk melakukan penelitian di SMAN 1 Grati, SMAN 1 Kejayan, SMAN 1 Bangil, SMAN 1 Gondang Wetan, SMAN 1 Purwosari, dan SMAN 1 Pandaan. (h) Meminta izin ke kepala sekolah atau Humas SMAN 1 Grati, SMAN 1 Kejayan, SMAN 1 Bangil, SMAN 1 Gondang Wetan, SMAN 1 Purwosari, dan SMAN 1 Pandaan untuk melaksanakan penelitian di sekolah tersebut. (i) Meminta surat balasan dari SMAN 1 Grati, SMAN 1 Kejayan, SMAN 1 Bangil, SMAN 1 Gondang Wetan, SMAN 1 Purwosari, dan SMAN 1 Pandaan bahwa telah melakukan penelitian tersebut.

SMA Negeri yang dijadikan sampel penelitian ini adalah SMAN 1 Grati, SMAN 1 Kejayan, SMAN 1 Bangil, SMAN 1 Gondang Wetan, SMAN 1 Purwosari, dan SMAN 1 Pandaan. Populasi penelitian ini adalah siswa kelas X dan XI SMA Negeri di Kabupaten Pasuruan. Pengambilan sampel berpedoman pada pendapat bahwa 
apabila subjeknya kurang dari 100, lebih baik diambil semua sehingga penelitiannya merupakan penelitian populasi. Selanjutnya jika subjek lebih dari 100 dapat diambil antara $10-15 \%$ atau $20-25 \%$ atau lebih (Marvasti, 2018). Karena subjek yang akan diteliti lebih dari 100, maka peneliti mengambil $10 \%$ dari jumlah subjek, yang mana masing-masing kelas diambil 30 siswa.

Penelitian ini melakukan pengujian konstruksi mengenai aspek yang akan diukur kepada para ahli (expert judment), yang mana peneliti meminta bantuan ahli di bidang pendidikan jasmani untuk memvalidasi instrumen penelitian. Mereka merupakan dosen Program Studi Pendidikan Jasmani dan Kesehatan, Fakultas IImu Keolahragaan, yakni Febrita Paulina Haenoeg, S.Pd, M.Pd, Drs. Tatok Sugiarto, S.Pd, M.Pd, dan Dr. Ari Wibowo Kurniawan, S.Pd, M.Pd. Kuisioner yang mereka validasi berjumlah 451 soal, yang akhirnya menjadi 82 soal. Selanjutnya dilakukan proses validitas kuisoner dengan jumlah 82 soal, untuk memvalidasi kuesioner peneliti mengunakan tenik korelasi poin biserial.

Setelah peneliti menguji butir soal kuesioner dengan hasil 74 butir soal, selanjutnya peneliti menguji tingkat kereliabilitas soal dengan menggunakan rumus yang memiliki syarat data menggunakan instrumen berskor 1 dan 0 yaitu rumus KR-21.

$$
r_{11}=\left(\frac{k}{k-1}\right)\left(1-\frac{M(k-M)}{k V_{t}}\right)
$$

Keterangan.

$r_{11}=$ reliabilias instrumen

$\mathrm{Vt}=$ varian total

$\mathrm{K}$ = banyaknya butir pertanyaan

$\mathrm{M}=$ skor rata-rata

Analisis data yang digunakan dalam penelitian ini menggunakan rumus persentase untuk mengkur tingkat persepsi siswa terhadap konsep pendidikan jasmani dan menggunakan rumus sebagai berikut.

$$
P=\Sigma \frac{F}{N} \times 100 \%
$$

Keterangan.

$\mathrm{P}=$ Angka persentase

$\mathrm{F}=$ Jumlah skor yang diperoleh dari menjawab kuesioner

$\mathrm{N}$ = Jumlah nilai keseluruhan dari jawaban benar

Sesudah mengetahui persentase dari hasil data yang diperoleh selanjutnya peneliti mengklasifikasikan kriteria yang menginterpresentasikan ke dalam lima kategori. Berikut di bawah ini tabel kriteria interprestasi skor.

Tabel 1. Kriteria interpretasi skor (Sujarwadi, 2011)

\begin{tabular}{lll}
\hline No & Persentase & Predikat \\
\hline 1 & $81-100 \%$ & Sangat baik \\
2 & $61-80 \%$ & Baik \\
3 & $41-60 \%$ & Cukup \\
4 & $21-40 \%$ & Kurang \\
5 & $0-20 \%$ & Sangat sekali \\
\hline
\end{tabular}

Sebelum melakukan uji beda, peneliti membandingkan data penelitian melalui prosedur uji prasyarat yang meliputi uji homogenitas dan uji normalitas. Setelah mengetahui data berbentuk parametrik atau non parametrik hasil uji prasyarat untuk mengetahui rumus uji beda. 


\section{Uji prasyarat}

Sebelum melakukan uji beda diharuskan melakukan uji prasyarat untuk mengetahui data berdistribusi parametrik atau non parametrik untuk mengetahui rumus uji beda yang cocok pada data tersebut. Dalam uji prasyarat terdapat uji normalitas dan uji homogenitas.

\section{Uji Normalitas}

Dalam penelitian ini untuk mengetahui data berdistribusi normal agar mengetahui data berbentuk parametrik atau non parametrik, peneliti menggunakan uji prasyarat normalitas Kolmogorov-Smirnov levene dengan bantuan aplikasi SPSS 25.

\section{Uji Homogenitas}

Dalam penelitian ini untuk mengetahui data berdistribusi normal agar mengetahui data berbentuk parametrik atau non parametrik, peneliti menggunakan uji prasyarat normalitas Levene dengan bantuan aplikasi SPSS 25.

\section{Perbedaan tingkat persepsi siswa-siswi kelas X dan XI di SMAN Kabupaten Pasuruan terhadap konsep pendidikan jasmani}

Untuk mengetahui perbedaan persepsi siswa kelas X dan XI, peneliti menggunakan uji beda U Mann-Whitney tes dengan menggunakan aplikasi SPSS 25. Hasil dari perhitungan uji prasyarat data tidak normal, maka peneliti menggunakan uji beda U Mann-Whitney.

\section{Perbedaan tingkat persepsi siswa perempuan dan laki-laki di SMAN Kabupaten Pasuruan terhadap konsep pendidikan jasmani}

Untuk mengetahui perbedaan persepsi siswa perempuan dan laki-laki, peneliti menggunakan uji beda MannWhitney tes dengan menggunakan aplikasi SPSS 25. Hasil dari perhitungan uji prasyarat data tidak normal, maka peneliti menggunakan uji beda U Mann-Whitney.

\section{HASIL}

Berdasarkan hasil validitas kuisoner yang berjumlah 1332 respoden dengan jumlah 82 soal dengan melibatkan responden Kabupaten Pasuruan, Kabupaten Banyuwangi, dan Kota Malang untuk mendapat soal yang valid menggunakan teknik korelasi biserial point mengunakan microsoft exel, didapat 74 soal yang valid. Selanjutnya peneliti mengukur reliabilitas kuisoner yang valid yang berjumlah 74 maka peneliti mengunakan rumus $k r 21$ dan diperoleh $0,809>0,054$ dapat disimpulkan tingkat relibiltas kuisoner baik atau konsisten. Selanjutnya peneliti menyajikan hasil penelitian persepsi siswa terhadap konsep pendidikan jasmani berupa tabel, berikut Tabel persepsi siswa SMA Negeri Kabupaten Pasuruan terhadap konsep pendidikan jasmani.

Tabel 2. Tingkat persepsi siswa di SMA Negeri Kabupaten Pasuruan terhadap konsep pendidikan Jasmani

\begin{tabular}{lcccc}
\hline \multirow{2}{*}{ Variabel } & \multicolumn{2}{c}{ Benar } & \multicolumn{2}{c}{ Salah } \\
\cline { 2 - 5 } & $\mathrm{F}$ & $\%$ & $\mathrm{~F}$ & $\%$ \\
\hline $\begin{array}{l}\text { Pengertian } \\
\text { pendidikan jasmani }\end{array}$ & 7404 & $89,42 \%$ & 876 & $10,58 \%$ \\
$\begin{array}{l}\text { Tujuan pendidikan } \\
\text { jasmani }\end{array}$ & 8706 & $86,37 \%$ & 1374 & $13,63 \%$ \\
$\begin{array}{l}\text { Kegiatan pendidikan } \\
\text { jasmani }\end{array}$ & 6736 & $81,35 \%$ & 1544 & $18,65 \%$ \\
\hline Jumlah & 22846 & $85,76 \%$ & 3794 & $14,24 \%$ \\
\hline
\end{tabular}

Berdasarkan tabel 2. dapat diuraikan pernyatan persepsi siswa terhadap konsep pendidikan jasmani dengan jumlah soal 74. Pada varibel pengertian pendidikan jasmani dengan no soal 1-23 yang menjawab benar berjumlah $7404(89,42 \%)$ sedangkan yang menjawab salah $876(10,58 \%)$. Pada variabel tujuan pendidikan jasmani dengan no soal $24-51$ yang menjawab benar berjumlah 8706 (86,37\%) sedangkan yang menjawab salah berjumlah 1374 (13,63\%). Pada variabel kegiatan PJOK dengan no soal 52-74 yang menjawab benar berjumlah $6736(81,35 \%)$ sedangkan yang menjawab salah berjumlah 1544 (18,65\%). Sehingga dapat 
disimpulkan sebagian responden $85,76 \%$ telah menunjukan bahwa persepsi siswa SMA Negeri Kabupaten Pasuruan terhadap konsep pendidikan jasmani adalah sangat baik.

Berdasarkan Tabel 2. dapat diuraikan hasil persentase penelitian pendidikan jasmani terdapat jawaban yang dijawab benar berjumlah 22.846 dan yang dijawab salah berjumlah 3.794 dengan nilai maksimal 26.640 yang dijawab 360 responden dari 74 butir soal. Hasil persentase terhadap konsep pendidikan jasmani 85,76\% telah memahami pengertian pendidikan jasmani. Dari hasil analisis tersebut jika ditampilkan dalam bentuk diagram pada gambar di bawah ini:

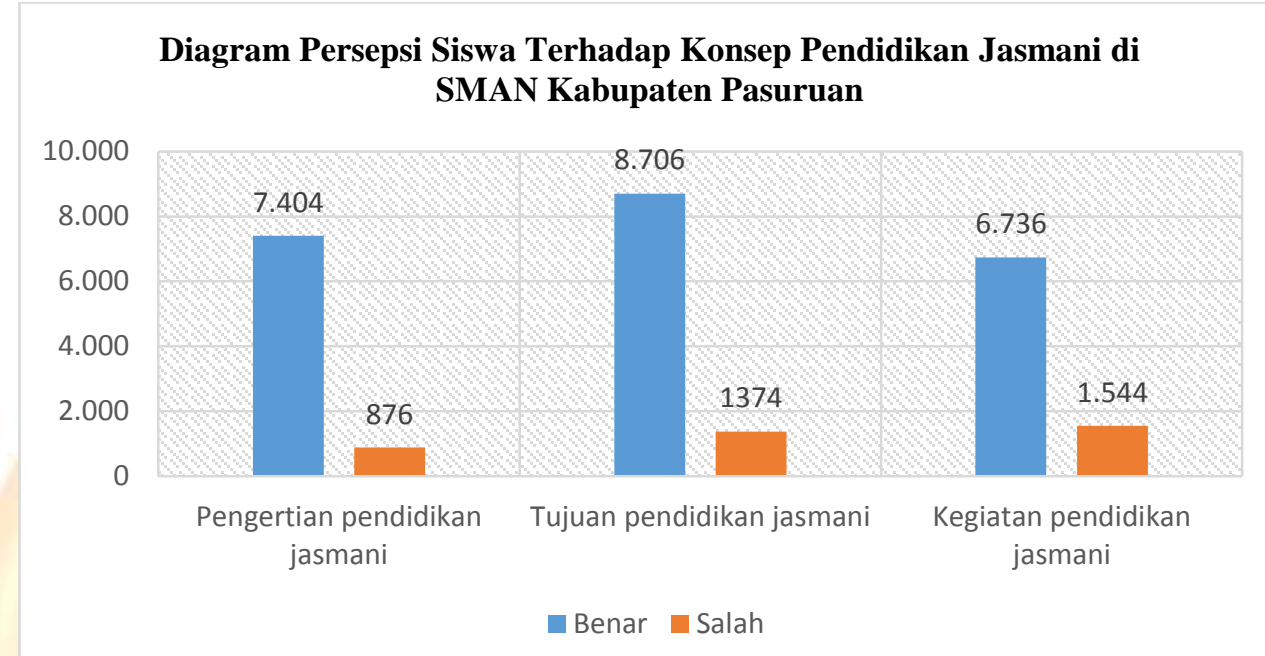

Gambar 1. Diagram Persepsi Siswa terhadap Konsep Pendidikan Jasmani di SMAN Kabupaten Pasuruan

Dalam penelitian ini peneliti menggunkan tes Kolmogorov-Smirnov Levene dengan bantuan aplikasi SPSS 25. Hasil uji normalitas perbedaan tingkat persepsi siswa laki dan perempuan terhadap konsep pendidikan jasmani diperoleh nilai signifikan sebesar 0,000. Karena taraf signifikan yang diperoleh adalah $>0.05$, maka dapat disimpulkan bahwa persepsi siswa laki-laki dan perempuan terhadap konsep pendidikan jasmani berdistribusi tidak normal atau ditolak.

\section{Perbedaan persepsi siswa laki- laki dan perempuan terhadapa konsep pendidikan jasmani}

Dalam penelitian ini peneliti mengunakan uji U Mann Whitney dengan bantuan SPSS 25 karena hasil uji normalitas berdistribusi tidak normal. Hasil dari pengolahan data dari U Mann Whitney dapat disimpulkan bahwa nilai signifikan 0,003 dengan taraf signifikansi $>0,05$ artinya hipotesis diterima. Dengan demikian hasil persepsi laki-laki dan perempuan terhadap konsep pendidikan jasmani mengalami perbedaan.

\section{Perbedaan persepsi siswa kelas $\mathbf{X}$ dan kelas $\mathbf{X I}$ terhadapa konsep pendidikan jasmani}

Dalam penelitian ini peneliti mengunakan uji U Mann Whitney dengan bantuan SPSS 25 karena hasil uji normalitas berdistribusi tidak normal. Hasil dari pengolahan data dari $U$ Mann Whitney dapat disimpulkan bahwa nilai signifikan 0,003 dengan taraf signifikansi $>0,05$ artinya hipotesis diterima. Dengan demikian hasil persepsi siswa kelas $\mathrm{X}$ dan kelas $\mathrm{XI}$ terhadap konsep pendidikan jasmani mengalami perbedaan.

Berdasarkan hasil penelitian diperoleh data persepsi siswa terhadap pengertian pendidikan jasmani di SMA Negeri Kabupaten Pasuruan tergolong sangat baik. Hal ini dapat dilihat dari banyaknya jawaban siswa yang menjawab benar. Berdasarkan penjelasan bahwa persepsi pada hakikatnya adalah proses kognitif yang dialami oleh setiap orang didalam memahami informasi tentang lingkungannya, baik lewat penglihatan, pendengaraan, penghayatan, perasaan, dan penciuman (Bohg et al., 2017). Melalui persepsi yang baik maka kita dapat berinteraksi dengan lingkungan kita, khususnya berinteraksi dengan guru karena guru merupakan fasilitas untuk mendapat pengetahuan. Persepsi siswa terhadap guru pendidikan jasmani adalah positif siswa menggap guru pendidikan jasmani sebagai pembimbing dan fasilitas untuk mendapatkan pengetahuan (Gray, Young, \& Waytz, 2012).

\section{PEMBAHASAN}

Persepsi mempunyai peranan yang penting dalam terwujudnya proses pembelajaran, sebab melalui persepsi yang baik maka dapat menumbuhkan persepsi yang benar dalam diri siswa sehingga dapat meningkatkan kualitas belajar siswa disekolah maupun di rumah dan lebih termotivasi lagi untuk mengikuti pembelajaran 
pendidikan jasmani. Hal tersebut sesuai dengan hasil presentase pengertian pendidikan jasmani yaitu sangat baik. Dengan hasil tersebut dapat dipahami bahwa interaksi guru dan siswa saat proses pembelajaran terkait pengertian pendidikan jasmani sangat baik. Guru mampu menjelaskan pengertian pendidikan jasamani dengan tepat kepada siswa sehingga siswa mampu menyerap penjelasan guru dengan benar. Persepsi siswa tentang faktor-faktor yang mempengaruhi pengajaran dan pembelajaran matematika merupakan faktor penting untuk keberhasilan dalam belajar dan bagian penting dalam proses pengajaraan dan pembelajaran matematika dalan meningkatkan kualitas kinerja siswa (Dauda, Jambo, \& Umar, 2016). Dalam proses persepsi perlu adanya perhatian sebagai langkah persiapan dalam persepsi. Hal tersebut karena keadaan menunjukkan bahwa individu tidak hanya dikenai oleh satu stimulus saja, tetapi individu dikenai berbagai macam stimulus yang ditimbulkan oleh keadaan sekitarnya. Namun demikian tidak semua stimulus tersebut mendapatkan respon individu untuk dipersepsi. Stimulus yang akan dipersepsi atau mendapatkan respon dari individu tergantung pada perhatian individu (Obokata et al., 2014).

Berdasarkan hasil penelitian persepsi siswa terhadap pengertian pendidikan jasmani di SMA Negeri Kabupaten Pasuruan yang menjawab salah cukup sedikit. Hal tersebut membuktikan bahwa siswa SMA Negeri Kabupaten Pasuruan telah banyak memahami pengertian pendidikan jasmani. Dengan demikian proses pembelajaran yang dilakukan melalui aktivitas gerak untuk meningkatkan kebugaran jasmani dapat dilakukan secara sistematik. Berdasarkan hasil yang didapat siswa sangat memahami pengertian pendidikan jasmani dan mempelajari mata pelajaran pendidikan jasmani dengan baik di sekolah. Berdasarkan penelitian yang dilakukan disimpulkan bahwa pemahaman siswa $X$ dan $X 1$ terhadap pengertian pendidikan jasmani termasuk baik dengan presentase $80,36 \%$ (ROKIM, 2016).

Berdasarkan hasil penelitian diperoleh data persepsi siswa terhadap tujuan pendidikan jasmani di SMA Negeri Kabupaten Pasuruan tergolong sangat baik. Dengan hasil tersebut dapat dipahami bahwa siswa dapat memahami dengan sangat baik terhadap tujuan pendidikan jasmani dan mampu mengaplikasikan mata pelajaran pendidikan jasmani dengan baik. Dibuktikan dengan hasil penelitian siswa yang menjawab salah cukup rendah. Dengan hasil tersebut maka menunjukkan bahwa persepsi siswa SMA Negeri Kabupaten Pasuruan tentang tujuan pendidikam jasmani sangat baik. Salah satu faktor yang mempengaruhi siswa dalam memahami tujuan pendidikan jasmani adalah kemauan diri siswa untuk belajar memahami tujuan pendidikan jasmani. Secara keseluruhan tujuan pendidikan jasmani telah diapalikasikan dengan baik oleh siswa, hal tersebut dapat dilihat dari hasil penilitian persepsi siswa terhadap tujuan pendidikan jasmani yang masuk dalam kategori sangat baik. Dengan hal tersebut siswa menerima mata pelajaran pendidikan jasmani dengan sangat baik. Berdasarkan peneltian siswa kelas $X$ beranggapan bahwa nilai persepsi siswa terhadap pelajaran pendidikan jasmani adalah baik, dan (13\%) 18 siswa beranggapan sangat baik (Dwi Hendro dan Anung, 2018).

Berdasarkan hasil penelitian diperoleh data persepsi SMA Negeri Kabupaten Pasuruan terhadap kegiatan pendidikan jasmani yaitu baik. Dengan diperolehnya data tersebut maka siswa dapat menyerap materi yang diperoleh dari guru. Melalui persepsi akan menimbulkan interaksi yang baik antara siswa dan guru sehingga proses pembelajaran yang efektif. Persepsi pada hakikatnya adalah proses kognitif yang dialami oleh setiap orang didalam memahami informasi tentang lingkungannya, baik lewat penglihatan, pendengaraan, penghayatan, perasaan, dan penciuman (Susanto, 2016). Dengan persepsi siswa yang benar tentang kegiatan pendidikan jasmani, maka siswa mempunyai dorongan untuk melakukan hal-hal yang positif terhadap kegiatan pendidikan jasmani. Persepsi adalah suatu proses yang terjadi dalam diri individu ketika menanggapi lingkunganya melalui proses pemikiran dan penasaraan yang kemudian menjadi dasar pertimbangan perilakunya (Mashuri, 2017). Dengan demikian persepsi merupakan suatu kemampuan memakanai yang telah didapat yang berupa pengalaman yang sudah dimiliki sebagai dasar untuk mengambil sikap. Dengan demikian dapat dipahami bahwa siswa telah memahami materi kegiatan pendidikan jasmani yang diberikan oleh guru saat mata pelajaran pendidikan jasmani berlangsung dan mempelajari mata pelajaran pendidikan jasmani dengan baik. .

Berdasarkan hasil penelitian persepsi siswa SMA Negeri Kabupaten Pasuruan terhadap konsep pendidikan jasmani yaitu sangat baik. Hal itu menunjukan bahwa siswa mempunyai minat untuk mengikuti pembelajaraan pendidikan jasmani. Persepsi berperan penting dalam terwujudnya proses pembelajaran yang efektif, melalui persepsi yang baik akan mewujudkan proses pembelajaran pendidikan jasmani yang benar. Hal tersebut dikarenakan motivasi merupakan salah satu faktor terbentuknya persepsi. Persepsi dapat dipengaruhi oleh motivasi guru, orang tua, dan materi pelajaran yang diberikan saat proses pembelajaran berlangsung dapat menyebabkan perbedaan persepsi dan dapat meningkatkan siswa dalam belajar matematika (Mutodi \& Ngirande, 2014). 
Hal tersebut dapat ditunjukkan dari hasil penelitian mengenai konsep pendidikan jasmani yang sangat baik. Siswa memperoleh persepsi konsep pendidikan jasmani melalui pengalaman atau rangsangan yang didapat dari proses pembelajaran yang disampaikan oleh guru. Persepsi pada hakikatnya adalah proses kognitif yang dialami oleh setiap orang didalam memahami informasi tentang lingkungannya, baik lewat penglihatan, pendengaraan, penghayatan, perasaan, dan penciuman (Mulyani \& Kurniadi, 2015).

Dengan demikian siswa telah memahami bahwa konsep pendidikan jasmani adalah suatu proses pembelajaran yang dilakukan melalui aktivitas gerak untuk meningkatkan kebugaran jasmani dapat dilakukan secara sistematik. Persepsi untuk melihat hasil dari guru menjelaskan materi pelajaran yang disampaikan pada proses pembelajaraan. Persepsi siswa diperlukan untuk menunjukkan keterkaitan sekolah dengan hasil pendidikan, sebab dengan persepsi siswa tentang lingkungan sekolah, maka siswa dapat berinteraksi dengan lingkungan.

\section{KESIMPULAN}

Persepsi siswa terdahap pengertian pendidikan jasmani SMA Negeri Kabupaten Pasuruan berdasarkan tabel tergolong sangat baik. Persepsi siswa terhadap tujuan pendidikan jasmani SMA Negeri Kabupaten Pasuruan berdasarkan tabel tergolong sangat baik. Persepsi siswa terhadap kegiatan pendidikan jasmani SMA Negeri Kabupaten Pasuruan berdasarkan tabel tergolong sangat baik. Persepsi siswa terhadap konsep pendidikan jasmani SMA Negeri Kabupaten Pasuruan berdasarkan tabel tergolong sangat baik. Perbedaan tingkat persepsi siswa kelas $\mathrm{X}$ dan $\mathrm{XI}$ terhadap konsep pendidikan jasmani SMA Negeri Kabupaten Pasuruan Menunjukkan ada perbedaan yang signifikan. Perbedaan persepsi siswa laki-laki dan perempuan terhadap konsep pendidikan jasmani SMA Negeri Kabupaten Pasuruan Menunjukkan ada perbedaan yang signifikan.

\section{DAFTAR PUSTAKA}

Bird, J., \& Bird, J. (2019). The Mann-Whitney test. In Mathematics Pocket Book for Engineers and Scientists. https://doi.org/10.1201/9780429294402-205

Bohg, J., Hausman, K., Sankaran, B., Brock, O., Kragic, D., Schaal, S., \& Sukhatme, G. S. (2017). Interactive perception: Leveraging action in perception and perception in action. IEEE Transactions on Robotics. https://doi.org/10.1109/TRO.2017.2721939

Dauda, B., Jambo, H. E., \& Umar, M. A. (2016). Students' Perception of Factors Influencing Teaching and Learning of Mathematics in Senior Secondary Schools in Maiduguri Metropolis, Borno State, Nigeria. Journal of Education and Practice.

Dwi Hendro dan Anung. (2018). Pengaruh Penerapan Ice Breaking pada Pembelajaran Pendidikan Jasmani Terhadap Peningkatan Motivasi Belajar. Jurnal Formatif.

Gray, K., Young, L., \& Waytz, A. (2012). Mind Perception Is the Essence of Morality. Psychological Inquiry. https://doi.org/10.1080/1047840X.2012.651387

Hansen, J., Sato, M., \& Ruedy, R. (2012). Perception of climate change. Proceedings of the National Academy of Sciences of the United States of America. https://doi.org/10.1073/pnas.1205276109

Manalu, D. L., Dwiyogo, W. D., \& Heynoek, F. P. (2020). Pengembangan Multimedia Interaktif Latihan Kekuatan Pada Matakuliah Spesialisasi Kondisi Fisik Dasar Untuk Mahasiswa Pendidikan Kepelatihan Olahraga Fakultas IImu Keolahragaan. Sport Science and Health, 2(1), 49-57. Retrieved from http://journal2.um.ac.id/index.php/jik/article/view/11158/5118

Marvasti, A. (2018). Research methods. In The Cambridge Handbook of Social Problems. https://doi.org/10.1017/9781108656184.003

Mashuri, H. (2017). Persepsi Siswa Terhadap Pembelajaran Guru Pendidikan Jasmani Di SMA Muhammadiyah Kediri. Jurnal SPORTIF: Jurnal Penelitian Pembelajaran. https://doi.org/10.29407/js_unpgri.v3i1.681

Mulyani, A., \& Kurniadi, D. (2015). Analisis Penerimaan Teknologi Student Information Terminal (S-IT) Dengan Menggunakan Technology Acceptance Model (TAM). Jurnal Wawasan IImiah. 
Mutodi, P., \& Ngirande, H. (2014). The influence of students' perceptions on mathematics performance. A case of a selected high school in South Africa. Mediterranean Journal of Social Sciences. https://doi.org/10.5901/mjss.2014.v5n3p431

Obokata, H., Wakayama, T., Sasai, Y., Kojima, K., Vacanti, M. P., Niwa, H., ... Vacanti, C. A. (2014). Stimulustriggered fate conversion of somatic cells into pluripotency. Nature. https://doi.org/10.1038/nature12968

ROKIM, M. (2016). Survei Keterlaksanaan Kurikulum 2013 Pada Guru Pjok Di Sma Negeri Se Kabupaten Nganjuk. Jurnal Pendidikan Olahraga Dan Kesehatan.

Sujarwadi, S. (2011). Validitas dan reliabilitas Instrumen penelitian. Metode Penelitian Survai.

Susanto, E. (2016). MODEL PERMAINAN AIR (WATER FUN GAMES) UNTUK MENINGKATKAN POTENSI BERENANG DAN PERILAKU KARAKTER SISWA SEKOLAH DASAR. Jurnal Pendidikan Jasmani Indonesia. 